\title{
Process Alignment for Sustainable Product Development: The Essential Role of Supplier and Customer Involvement Processes
}

\author{
Alex A. Alblas ${ }^{*}$, Kristian Peters, and Hans Wortmann \\ Faculty of Economics and Business, University of Groningen, The Netherlands \\ \{a.a.alblas,k.peters, j.c.wortmann\} @rug.nl
}

\begin{abstract}
Sustainable product development (SPD) has received increasing attention by scholars and practitioners recently. This paper explores two essential organizational processes to support SPD: supplier and customer involvement. The empirical study in six discrete manufacturing firms shows that various types of sustainability innovations (e.g., recycling or energy efficiency) imply discontinues change in the supply chain and/or customer context, and that these themes only can be implemented when the supplier and customer integration process is sufficiently supported. The results suggest that SPD requires alignment between the type of SPD innovation and the type of SPD organizational processes.
\end{abstract}

\section{Introduction}

During the past decade, sustainability has become increasingly popular in new product development (NPD). Various pressures and incentives to improve sustainability are mentioned in academic literature, such as laws and regulations, customer demands, cost reduction, improvement of quality, mitigation of risks, and improvement of image [1-5]. While its importance is more and more acknowledged in corporate mission and strategies of firms, sustainability oftentimes remains a lip service of motivated individuals working in operational levels of firms [6]. Many firms face difficulties in the management of sustainable product development (SPD) due to its far-reaching impacts on the organization, and the firms' business model, supply chain and operations [9-13]. Besides these practical complexities, the meaning of sustainability and its implications remain ambiguous in both literature and practice. Preliminary work reveals two conceptual complexities that can impede firms to manage SPD effectively. First, firms can regard sustainability as a homogeneous objective with a 'one size fits all' set of organizational practices. Instead, sustainability covers multiple objectives, and a wide array of sub-themes that consequently require tailored practices and aligned business models [15]. Secondly, firms can approach SPD as traditional NPD complemented with several design for environment (DfE) approaches (e.g., [17], [18]). SPD however shows increased complexity compared to traditional NPD, and therefore requires specific managerial approaches [6 - 9].

\footnotetext{
* Corresponding author.
} 
Given its importance and its problems, we seek to provide a more nuanced understanding of the relations between various types of sustainability, the organizations' business model (e.g., value proposition, infrastructure), and organizational processes (i.e., in this paper, supplier and customer integration). To accomplish this research aim, we conducted a multiple case study in which we investigate the type of sustainability that is currently pursued by the SPD function in a firm in relation to the type of supplier and customer integration in the early stages of SPD.

\section{Research Questions and Background}

The research focusses on three perspectives: (1) the types of sustainability innovation, depending on the firm's business model and sustainability focus; (2) the type of SPD organization with the specific focus supplier and customer involvement; and the ultimate aim, (3) SPD performance. These perspectives are reflected in three research questions:

- Can SPD innovations be categorized based on their type of sustainability focus and business model?

- What types of SPD organizational processes ${ }^{1}$ are required for what type of SPD innovations?

- How does the interaction between SPD innovations and SPD organizational processes $^{1}$ contribute to SPD performance?

In the first part of this section we will explain how sustainability can be characterized in different themes and business models. Then, we will explain the process management perspective that is used to characterize different types of SPD organizations. Finally, we will elaborate on some prior literature related to supplier and customer involvement in product development.

\subsection{Sustainability Focus: Sustainability Themes}

Sustainability has various meanings in business settings, and can be achieved or improved in product development in various ways. This section provides an overview of types of sustainability innovations in discrete manufacturing. The overview is the result of analyzing sustainability themes associated with products as reported in CSR reports of discrete manufacturing firms, and is subsequently supplemented with Design for Environment strategies. The details of the theoretical underpinnings and methodology can be found in [16].

Peters et al. [16] identify three levels to describe types of sustainability innovations in discrete manufacturing, namely 1) object level, 2) life cycle stage(s) and resource or release level, and 3) solution or measure level. In this paper, the object is a product, whereas other object foci can be e.g., packaging or production plant. For a product,

\footnotetext{
${ }^{1}$ In this paper the focus in on the investigation of the supplier and customer integration processes.
} 
sustainability themes and solutions concern one or more (or all) product life cycle stages, and one or more resource and release categories: 1) materials/parts, 2) energy and $\mathrm{CO}_{2}$ emissions, 3) (other) greenhouse gasses (GHG) emissions, and 4) hazardous and toxic substances. The combination of object + life cycle stage + resource or release, can be improved by various types of measures or solutions that product developers can implement through one or more Design for Environment (DfE) strategies, as described next. Table 1 presents an overview of sustainability themes with the related DfE strategies.

Table 1. Sustainability Themes with DfE strategies (see also Peters et al., [22])

\begin{tabular}{|c|c|c|}
\hline \multirow{2}{*}{$\begin{array}{l}\text { Resource / } \\
\text { release }\end{array}$} & \multicolumn{2}{|r|}{ Sustainability themes with DFE strategies } \\
\hline & Measure category & DfE Strategy \\
\hline \multirow[t]{3}{*}{ Materials } & \multirow[t]{2}{*}{ Dematerialization } & $\begin{array}{l}\text { Material use optimisation (linear system) } \\
\text { (Design for resource conservation; Avoidance of waste; } \\
\text { Reduction of material use; Design for durability) }\end{array}$ \\
\hline & & $\begin{array}{l}\text { Material and component reuse (circular system) } \\
\text { (Use recycled and recyclable materials; Design for } \\
\text { recycling; Design for disassembly; Design for re-use; } \\
\text { Design for remanufacturing) }\end{array}$ \\
\hline & Substitution & $\begin{array}{l}\text { Sustainable material use } \\
\text { (Use renewable material; Use bio degradable materials) }\end{array}$ \\
\hline \multirow[t]{3}{*}{$\begin{array}{ll}\text { Energy } & \& \\
\mathrm{co}_{2} & \end{array}$} & \multirow[t]{2}{*}{ Dematerialization } & $\begin{array}{l}\text { Energy efficiency (product/function) } \\
\text { (Use of lower energy content material; Design for } \\
\text { energy efficiency; Reduce weight of the product } \\
\text { (transport)/design for efficient distribution) }\end{array}$ \\
\hline & & $\begin{array}{l}\text { Energy efficiency (system) } \\
\text { (Design for energy efficient system; Design for use } \\
\mathrm{CO}_{2} \text { in other functions in system) }\end{array}$ \\
\hline & Substitution & $\begin{array}{l}\text { Sustainable energy } \\
\text { (Design for cleaner use; Design for renewable energy } \\
\text { sources) }\end{array}$ \\
\hline \multirow[t]{2}{*}{$\begin{array}{l}\text { Ghg/ } \\
\text { Hazardous } \\
\text { Substances }\end{array}$} & Dematerialization & $\begin{array}{l}\text { Cleaner use } \\
\text { (Minimize GHG and toxic or hazardous substances; } \\
\text { Design for re-use) }\end{array}$ \\
\hline & Substitution & $\begin{array}{l}\text { Clean substances and emissions } \\
\text { (Avoid GHG, and toxic or hazardous substances; De- } \\
\text { sign for use GHG in other functions in system }\end{array}$ \\
\hline
\end{tabular}

DfE strategies are design principles and procedures to develop environmentally conscious products [19], [20]. The measures, solutions and DfE strategies can subsequently be divided in two categories, namely dematerialization strategies and substitution strategies [21], [22]. Dematerialization concerns increased resource productivity and/or less waste, e.g., design for durability or design for energy efficiency. In addition, we discern where the system boundaries of the solutions or measures are drawn. Dematerialization can be achieved by solely looking at the product (e.g., using less materials, or consume less energy), but it can also be achieved by influencing the system design in which the product ultimately is used (e.g., redesign of both system and pump for energy efficiency, or use waste produced by product in different 
function in system, or make sure product parts are re-used after end-of-life). Substitutive measures imply a change to a substitute resource or release leading to a more sustainable product, e.g., design for renewable material and design for non-toxic and non-hazardous substances.

\subsection{Sustainable Business Model}

A business model is affected by the firms' strategy towards sustainability. Its effectiveness is influenced by the way customer perceive the sustainable value proposition, and its efficiency is influenced by the firm organizational processes to best encounter those desires. "The essence of a business model is in defining the manner by which the enterprise delivers value to customers, entices customers to pay for value, and converts those payments to profit" [23].

Literature is diverse in terms of the attributes that constitute a business model. Table 2 presents an overview of various attributes mentioned in the literature. In this study we will analyze the companies on (1) Market segment, (2) Value proposition, (3) Elements of value chain (distribution channel, customer relationships), (4) Positioned in value network (network partners), (5) Competitive strategy.

Table 2. Different business model attributes

\begin{tabular}{|c|c|c|c|}
\hline $\begin{array}{l}\text { Verhulst and Boks } \\
(2012)[24]\end{array}$ & $\begin{array}{l}\text { Chesbrough and Rosen- } \\
\text { bloom (2002) [25] }\end{array}$ & $\begin{array}{l}\text { Osterwalder } \\
{[26]}\end{array}$ & $\begin{array}{l}\text { Crawford and DiBe- } \\
\text { nedetto (2011) [27] }\end{array}$ \\
\hline $\begin{array}{l}\text { Sustainable design } \\
\text { strategies }\end{array}$ & $\begin{array}{l}\text { Xerox spin off business } \\
\text { models (not SPD) }\end{array}$ & $\begin{array}{l}\text { Business model building } \\
\text { for planet, people and } \\
\text { profit }\end{array}$ & $\begin{array}{l}\text { New products man- } \\
\text { agement }\end{array}$ \\
\hline $\begin{array}{l}\text { - Value proposition } \\
\text { - Customer interface } \\
\text { - Infrastructure } \\
\text { - Financial viability }\end{array}$ & $\begin{array}{l}\text { - Market } \\
\text { - Value proposition } \\
\text { - Value chain } \\
\text { - Value network } \\
\text { - Cost and profit } \\
\text { - Competitive strategy }\end{array}$ & $\begin{array}{l}\text { - Customer segment } \\
\text { - Value proposition } \\
\text { - Customer relation- } \\
\text { ships } \\
\text { - Distribution channels } \\
\text { - Partner network } \\
\text { - Key resources } \\
\text { - Key activities } \\
\text { - Revenue stream } \\
\text { - Cost structure }\end{array}$ & $\begin{array}{l}\text { - Market focus } \\
\text { - End-user bene- } \\
\text { fit/insight } \\
\text { - Technological focus }\end{array}$ \\
\hline
\end{tabular}

\subsection{Type of SPD Organizational Processes}

The introduction of sustainability in NPD introduces complexity e.g., [14]. Complexity can be reduced by the employment of process management techniques by the reduction of variance and the improvement of stability and repeatability [28-31]. Process management is based on a view of an organization as a system of interlinked processes. It involves concerted efforts to map, improve, and adhere to organizational processes [30]. The principle postulation of this study is that the type of sustainability innovation needs to be aligned with specific SPD processes. To illustrate this point this paper specifically investigates the role of suppliers and customers processes in relation to different types of sustainability innovations. We expect that firms need 
address and (re)organize supplier and customer integration processes for many types of sustainability innovations.

For example, to implement remanufacturing, a company needs to efficiently organize reverse logistics cf. [32]. For reverse logistics, customers have to be able and willing to return end of life products. The product design directly influences the effectiveness of this process, because it influences the ease of contribution in terms of size, ease of disassembly, traceability, etc. Furthermore, in order to influence the user phase in the product life cycle, a product has to be aligned not only with the customer requirements in terms of functionality, but also with the acceptance of specific sustainability functionality and the existing infrastructure at customers' sites. Therefore, alignment is required between the product design and the suppliers' and customers' infrastructures.

Previous literature has shown that early supplier involvement is an important process in supply chain design, product design and process design e.g., [33]. Petersen et al. [33] distinguish between three types of supplier integration: (1) White box design and specification decisions are the responsibility of the company, but discussions are held with suppliers about this with suppliers; (2) Grey box - formal or informal involvement of suppliers in development, which may include information and technology sharing and joint decision making regarding design specifications; (3) Black box - almost complete supplier responsibility for the purchased item with only review on the purchased item's specifications by the buying company.

Concerning the customer perspective various authors mention the importance of customer empowerment in product development in terms of their engagement to create ideas for new product designs; and their permission to select the product designs to be produced e.g., [34]. Moreover, the type of customer involvement affects the type of engineering work that is conducted and impacts the overall product delivery strategy of a firm [35]. Customer involvement can vary from very limited involvement, to very intensively involvement, i.e., having lots of influence on the design decisions of a company. Thus, firms could operate according to open product delivery strategies that allow customers to specify engineering work completely (fully engineer-to-order), whereas on the other side of the spectrum, firms operate according to a closed product delivery strategies towards customers (e.g., make to order, assembly to order, make to stock). The above-mentioned types of supplier and customer integration will be used to categorize the cases in their intensity of supplier and customer integration in SPD.

\section{$3 \quad$ Methodology}

Present research is an exploratory multiple case study [36]. The cases used for this study were selected by combining two sampling strategies: homogenous sampling and (maximum) variation sampling. With regard to the homogeneity of the sample, we concentrate on companies that aim to improve the sustainability of their products in product development, and who operate in discrete manufacturing industries. With regard to variation, we selected either companies for whom the improvement concerns 
the first step into managing sustainability in product development, or companies for whom it concerns further developing and expanding SPD. The selection process resulted in six discrete technology manufacturers (i.e., company A, B, C, D, E, F).

Data collection and analysis comprised the following steps. Firstly initial interviews were conducted to investigate the roles of suppliers and customers in SPD. Then, literature was analyzed and a framework was constructed. Based on the operationalization, we collected generic data on the roles of suppliers and customer in SPD. Subsequent data will be collected about the roles, the processes and decisions of suppliers and customers in cooperation with the companies in the different stages of the FFE. The data was reduced and condensed by using tables and data displays following the framework.

The results of the data analyses are summarized in in two figures (Figure 1 (a), (b)). Figure 1a represents the positions of the cases on supplier and customer integration, and Figure $1 \mathrm{~b}$ positions the sustainability themes on the required supplier and customer integration. The position of the cases and sustainability themes on supplier and customer integration are assessed based on the dimensions presented in Section 2.

\section{Results}

In this section we describe the case study results. For each case we will give a brief overview of their business model and sustainability theme, followed by an analysis of how the case company organized supplier and customer integration.

Figure 1(a) and Figure 1(b) illustrate together the link between the (a) position of the cases and (b) the various sustainability themes a firm can focus on given the position on supplier and customer integration. Figure 1(b) illustrates that the various sustainability themes differ in the required supplier and customer integration. For example, Materials Dematerialization: materials use optimization (linear system)' requires limited downstream integration, because the organization of a return flow is not required and the impact the customer specification is limited (see Figure 1). The 'Materials Dematerialization: materials and component reuse' theme requires more downstream integration, because the organization of the return flow and a specific consideration of remanufacturing in the product design are required.

The majority of case companies (i.e., Companies A, C, E and F) make products that have multiple sustainability characteristics, e.g., durability, safety, reliability, maintenance-free, and energy efficiency, as a result of their past en present business models. Today, these companies intend to incorporate new sustainability characteristics in their products, or bring existing qualities to a higher level. It is however questionable whether the business models of companies $\mathrm{C}, \mathrm{E}$ and $\mathrm{F}$ enable new sustainability innovations. In order to illustrate this point, we discuss the business models of these three case companies, starting with company's $\mathrm{C}$, in relation to the type of sustainability innovation each company intends to realize within SPD. Additionally, we contrast the 'problematic' cases with other cases that have been more successful in SPD, or that have an enabling business model in place. 
(a)

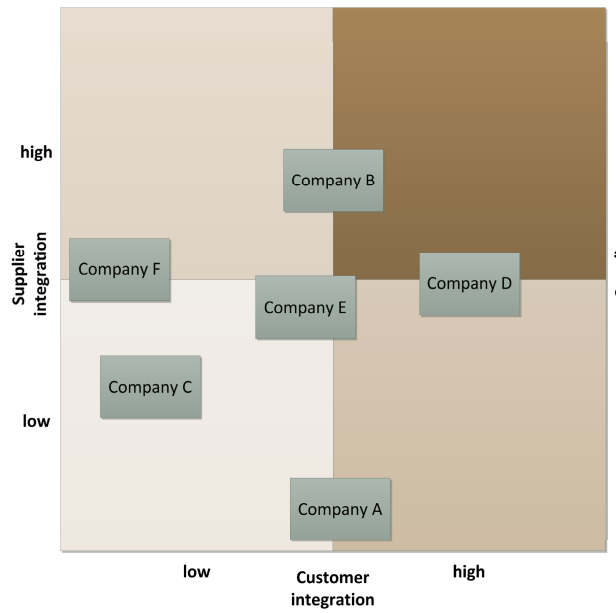

(b)

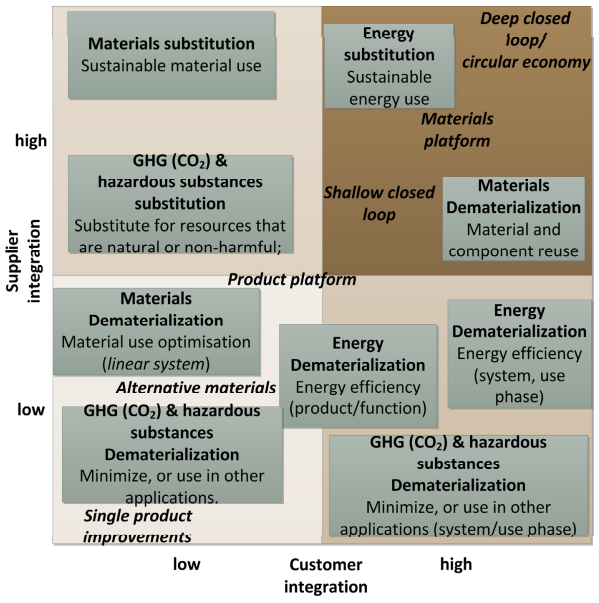

Fig. 1. Position of the cases and sustainability themes

Due to new EU law and regulation regarding the energy consumption of centrifugal pumps, Company $\mathrm{C}$ concentrates on energy efficiency innovations. Although Company $\mathrm{C}$ already studied the possibilities to increase energy efficiency, because they expected the recently implemented EU law and regulations for energy consumption, not much has changed. According to Company C's R\&D manager: "the organization, and especially the sales force, do not fully embrace energy efficiency".

Company $\mathrm{C}$ is a traditional supplier of centrifugal pumps: based on customer requirements (i.e., usually a certain pump capacity) the most economic pump is selected and sold to the customer. The newer and more energy efficient pumps lead to a higher initial list price for the pump, but should improve the Total Cost of Ownership. But Company C's sales force are confronted with customers that do not perceive energy efficient pumps as an attractive advantage, and therefore still prioritize a lower initial cost price over energy efficiency savings or environmental advantages. This problem especially applies to Company $\mathrm{C}$ customers who are not end-user of the product yet, for instance original equipment manufacturers (OEM's). Another reason is the lack of information, tools and skills of the sales personnel regarding the implementation and possibilities of the pump in an energy efficient system for the customer. Thus, Company C's current business model is not yet compatible with the new sustainability focus of Company $\mathrm{C}$.

Company A, also a manufacturer of pumps, employs a different business model. Instead of waiting on customers telling them what kind of pumps they want based on a few parameters as in Company C, Company A aims to be involved as early as possible in the design of the system in which their pumps will operate. In this way, Company A can ensure their customers buy pumps that function optimal in their systems from both economical as well as environmental points of view. Moreover, Company A can advise their customer to adjust certain aspects of their system, for instance piping diameters or 
hydraulic head, so that pumps will even function more efficient. Company A's level of integration in the value chain can be an example for Company $\mathrm{C}$.

Company E supplies electric switching gear to utility companies and industries. In utility companies, $\mathrm{CO}_{2}$ footprint and climate change are the most important sustainability themes. Company $\mathrm{E}$ has therefore adopted $\mathrm{CO}_{2}$ reduction as a major theme for sustainability innovations. Moreover, unlike most switching gear equipment produced by competitors, Company E's equipment does not contain sulfur hexafluoride $\left(\mathrm{SF}_{6}\right)$, which is the most potent greenhouse gas in the world (23,900 times higher global warming potential than $\mathrm{CO}_{2}$ ). Despite this unique characteristic, and Company E's other SPD efforts to contribute to the $\mathrm{CO}_{2}$ theme of their customers, sustainable product successes are mixed. According to Company E's R\&D manager: "the share of our equipment in the total customer's $\mathrm{CO}_{2}$ footprint is marginal". Consequently, customers have better alternatives to invest in than Company E's $\mathrm{CO}_{2}$-friendly switching gear. Innovations aimed at $\mathrm{CO}_{2}$ reduction do not fit within the current business model of Company E. Company $\mathrm{E}$ is now reconsidering its type of sustainability innovations (e.g., material efficiency), and explores how this may affect their current business model (e.g., offering leasing construction).

Lastly, Company $\mathrm{F}$ has traditionally concentrated on offering high efficient gasbased solutions to generate hot water and heating. It has recently developed new techniques, most notable combined cogeneration technology. Yet this technology is still too expensive given current market conditions, and moreover, requires changes in the energy market (e.g., the household as a supplier of energy) that have not been implemented. Company $\mathrm{F}$ therefore wants to explore other sustainability opportunities, such as material efficiency. Because Company $\mathrm{F}$ intends to stick to its current business model, the possibilities for material efficiency improvements are very limited. In this respect, Companies B and D have shown that significant material efficiency gains can only be achieved when the business model is aligned.

The data presented in Figure 1 show that the case companies vary in their process management capability with respect to customer and supplier integration and thus their ability to implement sustainability themes. It is for example illustrated that Company $\mathrm{C}$ has challenges in supplier and customer integration. They produce centrifugal pumps, which have substantial impact on energy consumption in the use phase and the overall sustainability performance of the customers water management system. These customers, however, are required to be convinced, and cooperation is needed in the design of the overall water management system in order to be able to improve the 'Energy Dematerialization: energy efficiency of the system and use phase' theme (see Figure 1).

Based on the interviews, generic patterns on supplier and customer integration are found. Figure 1(a) illustrates that Companies C, A, E, and F have limited supplier and customer integration whereas Companies B and D have more integration. All in all, we found that early supplier involvement is perceived as very important for SPD with very innovative business models and/or transitions towards new business models and very ambitious sustainability initiatives. One of the key findings is that, because of the lack of supplier and customer integration, several cases have limited influence on the supply chain, which leads to challenges to implement new sustainability business 
models. In order to be able to reach their sustainability goals, these firms are required to align their supplier and customer integration with their sustainability focus and their sustainability business model.

\section{$5 \quad$ Discussion and Conclusion}

The first research question of the study is: "Can SPD innovations be categorized based on their type of sustainability focus and business model?". Present study has shown that SPD innovations can change substantially due to their differences in focus, scope, impact and type of business model. We use the sustainability themes framework developed in previous studies as a starting point [15], [16]. Further research could aim at the development of a more detailed SPD innovation typology.

The second research question is: "What types of SPD organizational processes are required for what type of SPD innovations?". In this study the focus was on the specific processes related to supplier and customer integration. The results show contribution, however this depends on the type of SPD innovation a firm focusses on. Some sustainability foci and business models require more integration then others. The authors intent to investigate in future research other types of SPD organizational processes in different SPD stages that contribute to SPD performance.

The third research question is: "How does the interaction between SPD innovations and SPD organizational processes contribute to SPD performance?". Based on the study, several generic patterns are distilled. Figure 2 illustrates the proposed relation between SPD alignment between SPD organization and SPD innovation, and SPD performance. 'SPD alignment' refers to ensuring that the 'SPD organization' characteristics are consistent with the 'SPD innovation' characteristics.

One of the most important observations is that when firms persist in the assumption that traditional NPD and engineering methods (such as traditional DfEs) deliver enough support to create sustainable products, the eventual proportion of sustainable products in the total portfolio of these companies will be limited. Instead, it is expected that solutions towards SPD performance are related to the ability of a firm to align the type of SPD innovation (e.g., type of business model, type of sustainability focus) with the SPD organization (e.g., type of SPD process, SPD stage) (See Figure 2).

The case examples demonstrate that many of the present organizational routines within NPD often do not facilitate organizational or external level activity aimed at sustainability. The unaligned cases call for process management of various processes of SPD that enable the exploration for new sustainability opportunities and business models. Future research could focus on investigating important process areas and related practices in SPD that facilitate different forms of SPD innovation. It is furthermore assumed that companies show diversity in their maturity in SPD: some of them focus on relative simple sustainability business models, while others have more advanced ambitions with the required advanced SPD organization. The area of process maturity in relation to SPD is thus promising a direction for further research. 


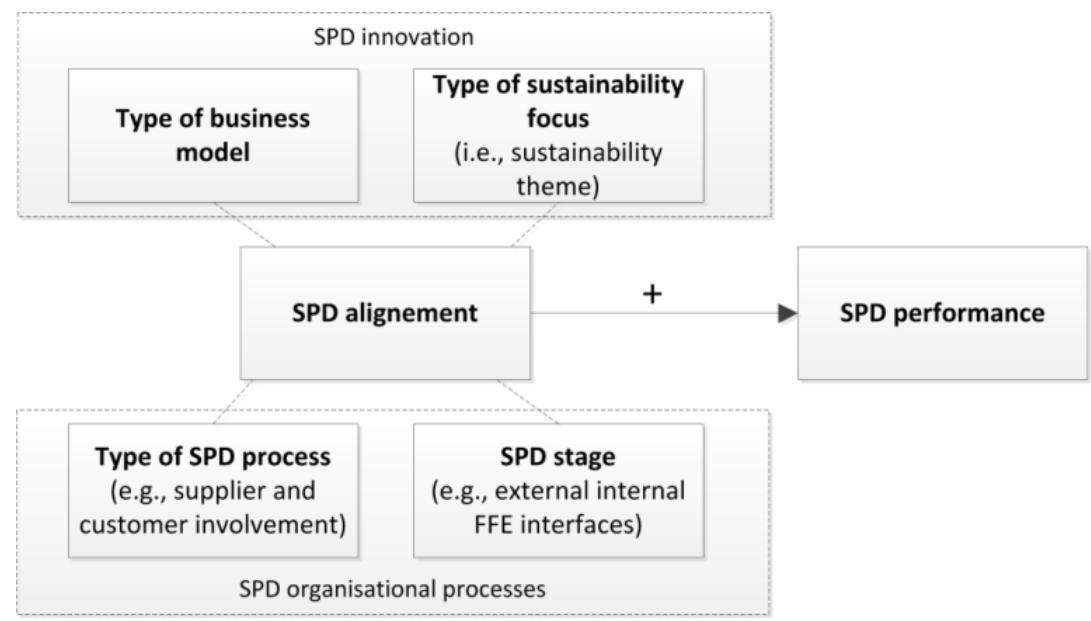

Fig. 2. Proposed Framework: SPD alignment

Acknowledgements. The authors gratefully acknowledge the support of the Innovation-Oriented Research Programme 'Integral Product Creation and Realization (IOP IPCR)' of the Netherlands Ministry of Economic Affairs.

\section{References}

1. Porter, M.E., Van der Linde, C.: Toward a New Conception of the EnvironmentCompetitiveness Relationship. The Journal of Economic Perspectives 9(4), 97-118 (1995)

2. Bansal, P., Roth, K.: Why Companies Go Green: A Model of Ecological Responsiveness. The Academy of Management Journal 43(4), 717-736 (2000)

3. Seuring, S., Müller, M.: From a literature review to a conceptual framework for sustainable supply chain management. Journal of Cleaner Production 16(15), 1699-1710 (2008a)

4. Horbach, J.: Determinants of environmental innovation-New evidence from German panel data sources. Research Policy 37, 163-173 (2008)

5. Forsman, H.: Environmental Innovations as a Source of Competitive Advantage or Vice Versa? Business Strategy and the Environment (2013) (Advance online publication) doi:10.1002/bse. 1742

6. Alblas, A.A., Peters, K., Wortmann, J.C.: Fuzzy sustainability incentives in new product development: Empirical explorations of sustainability challenges in manufacturing companies. International Journal of Operations and Production Management (2013) (accepted for publication)

7. Hall, J., Vredenburg, H.: The challenges of innovating for sustainable development. MIT Sloan Management Review 45(1), 61-68 (2003)

8. Pujari, D.: Eco-innovation and new product development: understanding the influences on market performance. Technovation 26(1), 76-85 (2006)

9. Driessen, P.H., Hillebrand, B., Kok, A.W.K., Verhallen, T.M.M.: Green New Product Development: The Pivotal Roleof Product Greenness. IEEE Transactions on Engineering Management (in press, 2013) 
10. Sroufe, R., Curkovic, S., Montabon, F., Menyk, S.A.: The new product design process and design for environment: Crossing the chasm. International Journal of Operations \& Production Management 20(2), 267-291 (2000)

11. Seuring, S., Müller, M.: Core Issues in Sustainable Supply Chain Management: a Delphi Study. Business Strategy and the Environment 17, 455-466 (2008)

12. Dangelico, R.M., Pujari, D.: Mainstreaming green product innovation: why and how companies integrate environmental sustainability. Journal of Business Ethics 95(3), 471-486 (2010)

13. Pinske, J., Kolk, A.: Challenges and Trade-Offs in Corporate Innovation for Climate Change. Business Strategy and the Environment 19, 261-272 (2010)

14. Matos, S., Hall, J.: Integrating Sustainable Development in the Supply Chain: The Case of Life Cycle Assessment in Oil and Gas and Agricultural Biotechnology. Journal of Operations Management 25(6), 1083-1102 (2007)

15. Peters, K., Alblas, A.A., Wortmann, J.C.: Selection of Big Themes in Sustainable Product Development: a framework of actions and measures in business as found in CSR reports and case companies. In: Proceedings of ERSCP-EMSU 2013 Conference: Bridges for a More Sustainable Future: Uniting Continents and Societies (2013)

16. Peters, K., Alblas, A.A., Wortmann, J.C.: Addressing the gap between manufacturers' sustainability intentions and effective sustainable product development: The Big Themes Framework. In: Proceedings of the 20th EurOMA Conference: Operations Management at the Heart of the Recovery (2013)

17. Kobayashi, H.: Strategic evolution of eco-products: a product life cycle planning methodology. Research in Engineering Design 16, 1-16 (2005)

18. Choi, J.K., Nies, L.F., Ramani, K.: A Framework for the Integration of Environmental and Business Aspects Toward Sustainable Product Development. Journal of Engineering Design 19, 431-446 (2008)

19. Srivastava, S.K.: Green supply-chain management: A state-of-the-art literature review. International Journal of Management Reviews 9(1), 53-80 (2007)

20. Boks, C., Stevels, A.: Essential perspectives for design for environment: Experiences from the electronics industry. International Journal of Production Research 19, 4021-4039 (2007)

21. Robèrt, K.-H., Schmidt-Bleek, B., Aloisi de Larderel, J., Basile, G., Jansen, J.L., Kueher, R., Price Thomas, P., Suzuki, M., Hawken, P., Wackernagel, M.: Strategic sustainable development - selection, design, and synergies of applied tools. Journal of Cleaner Production 10, 197-214 (2002)

22. Waage, S.A., Geiser, K., Irwin, F., Weissman, A.B., Bertolucci, M.D., Fisk, P., Basile, G., Cowan, S., Cauley, H., McPherson, A.: Fitting together the building blocks for sustainability: A revised model for integrating ecological, social, and financial factors into business decision-making. Journal of Cleaner Production 13(12), 1145-1163 (2005)

23. Teece, D.J.: Business Models, business strategy and innovation. Long Range Planning 43(2), 172-194 (2010)

24. Verhulst, E., Boks, C.: Sustainable design strategies in practice and their influence on business models. In: Design for Innovative Value Towards a Sustainable Society, pp. 413-418. Springer, Netherlands (2012)

25. Chesbrough, H., Rosenbloom, R.S.: The role of the business model in capturing value from innovation: evidence from Xerox Corporation's technology spin-off companies. Industrial and Corporate Change 11(3), 529-555 (2002)

26. Osterwalder, A., Pigneur, Y.: Business model generation: A handbook for visionaries, gam changes and challengers. Wiley (2010) 
27. Crawford, C.M., DiBenedetto, C.A.: New products management. Tata MCGraw-Hill Eductation (2011)

28. Winter, S.: Organizing for continuous improvement: Evolutionary theory meets the quality revolution. In: Baum, J., Singh, I. (eds.) Evolutionary Dynamics in Organizations, pp. 90-108. Oxford University Press, New York (1994)

29. Benner, M.J., Tushman, M.L.: Process Management and Technological Innovation: A Longitudinal Study of the Photography and Paint Industries. Administrative Science Quarterly 47(4), 676-706 (2002)

30. Benner, M.J., Tushman, M.L.: Exploitation, Exploration, and Process Management: The Productivity Dilemma Revisited. Academy of Management Review 28(2), 238-256 (2003)

31. Adler, N., Benner, M.J., Brunner, D.J., MacDuffie, J.P., Osono, E., Staats, B.R., Takeuchi, H., Tushman, M.L., Winter, S.G.: Perspectives on the productivity dilemma. Journal of Operations Management 27(1), 99-113 (2009)

32. Sarkis, J., Zhu, Q., Laic, K.: An organizational theoretic review of green supply chain management literature. International Journal of Production Economics 130(1), 1-15 (2011)

33. Petersen, K.J., Handfield, R.B., Ragatz, G.L.: Supplier integration into new product development: coordinating product, process and supply chain design. Journal of Operations Management 23(3), 371-388 (2005)

34. Fuchs, C., Schreier, M.: Customer empowerment in new product development. Journal of Product Innovation Management 28(1), 17-32 (2011)

35. Veldman, J., Alblas, A.: Managing design variety, process variety and engineering change: a case study of two capital good firms. Research in Engineering Design 23(4), 269-290 (2012)

36. Yin, R.K.: Case study research: Design and methods. Sage, Thousand Oaks (2003) 